University of Nebraska - Lincoln

DigitalCommons@University of Nebraska - Lincoln

Library Philosophy and Practice (e-journal)

Libraries at University of Nebraska-Lincoln

November 2021

\title{
Challenges and prospects for cataloguing and classification in academic libraries in Kwara State, Nigeria: a case study
}

Abdrahman Atanda MOUSTAPHA

Kwara State University, Nigeria, abdrahman.moustapha@kwasu.edu.ng

Abdrahman Atanda MOUSTAPHA

Kwara State University, Nigeria, abdrahman.moustapha@kwasu.edu.ng

Follow this and additional works at: https://digitalcommons.unl.edu/libphilprac

MOUSTAPHA, Abdrahman Atanda and MOUSTAPHA, Abdrahman Atanda, "Challenges and prospects for cataloguing and classification in academic libraries in Kwara State, Nigeria: a case study" (2021). Library Philosophy and Practice (e-journal). 6380.

https://digitalcommons.unl.edu/libphilprac/6380 


\title{
Challenges and prospects for cataloguing and classification in academic libraries in Kwara State, Nigeria: a case study
}

\author{
Abdrahman Atanda MOUSTAPHA (CLN, NLA) \\ Kwara State University Library, Nigeria. \\ E-mail: abdrahman.moustapha@kwasu.edu.ng.
}

Phone: +2348033660831 . 


\begin{abstract}
The study aimed to investigate the challenges and prospects of cataloguing and classification in academic libraries in Kwara State that focus on the Kwara State University Library.The study adopted the descriptive survey design. The study population consists of 50 practicing librarians who attended the Nigerian Library Association Annual Workshop, 2020 held at the State LibraryIlorin, Kwara State, Nigeria. A questionnaire entitled "Cataloguing challenges and prospects and a classification questionnaire containing closed elements was used to collect data for the study. The results revealed insufficient staffing, lack of modern tools, difficulties in cataloguing and classification backlogs, insufficient motivation, etc., as there are some challenges facing the technical departments of the studied academic library. The study also reveals, as an indication of a brighter future or good prospects for the technical divisions in the library studied, the increased advocacy for library automation, training opportunities available outside the country, introduction of an information management system, rapid transition from the manual method to the computerized method, etc. Based on the results, some recommendations were made.
\end{abstract}

Keywords: Technical Section, Cataloguing, Classification, Academic Libraries, Kwara State University, Library 


\section{INTRODUCTION}

Cataloguing and classification are two different types of technical jobs that professional librarians perform in all types of libraries in particular, academic libraries where large numbers of collections are usually obtained and processed. These two functions (cataloguing and classification) are performed either manually or electronically in some academic libraries. In some cases, both methods (manual and electronic) are used simultaneously in some libraries. For example, jobs in the majority of university libraries in Kwara State are still done manually, while very few Automated Catalog (OPAC) is used. The fact is that whether it is manual or electronic, the procedure for preparing materials remains the same. Each element in the book is described using a standard format. The book cataloguing procedure is guided by the rules described in the second edition of the Anglo-American Cataloguing Rules (AACR2). In the cataloguing description given in Isyaku, Bello, and Ado (2018), he explained that cataloguing is the process of describe library materials using its bibliographic data in a logical and systematic order as described in cataloguing tool such as AACR2 (52p.). There are two types of cataloguing, descriptive and subject cataloguing. Descriptive cataloging uses the bibliographic data in the material to describe the item while subject cataloguing determines the subject content of the item. Hence, this material description process is followed by assigning classes to the items. The assignment of classes to library material is guided by standard classification schemes (Library of Congress (LC) Classification Scheme, Dewey Decimal Classification Scheme (DDC), Bliss Classification Scheme (BC), etc.)that is generally accepted and used worldwide. Word classification is used to describe the logical and systematic arrangement of library collections 
usually according to subject content, through their likeness and treatment. In other words, it is the process of grouping similar library materials according to the content of their subject matter (Isyaku, Bello \& Ado, 2018, 52p.). Thus, Esther is cited in Isyaku, Bello, and Ado (2018) who defines classification as the process of grouping library materials according to the contents of their subject matter which helps in grouping the same topic together and separating what differs and approximating those that have a relationship. The key to classificationis to group similar materials together and to assign classes well to grouped materials. Due to the complex nature of cataloguing and classification functions, some of the challenges specific to this section are related. Each section of the library has one challenge or the other, but experience shows that the sections associated with the cataloguing and classification section are more prominent. Consequently, the majority of librarians lack interest in working in the department, and as a result many librarians have not worked in the technical department (Posigha, Asaba \& OberhiriOruma, 2018: 178p.). Despite the challenges associated with cataloging and classification, it can be said that the future is bright especially with the increasing adoption of modern information and communication technologies (ICT) in the library. In fact, experience shows that increasing the adoption of ICTs in the library has given a new face and a new dimension to the technical departments of many libraries. Duties which were handled incrementally or completely are now handled by technological devices in many academic libraries in Nigeria. In addition to the innovative technological devices adopted in academic libraries, some library managers see the department as the engine room for the library in terms of access to the library's holdings. Thus, incentives like cash reward, opportunity to attend workshop and conferences, training, etc., are now available to staff in the department in some libraries. 


\section{Problem Statement}

The mechanism for accessing the required information is the primary responsibility of the technical department. Despite the importance of the department, it is still beset with many challenges such as insufficient staffing, lack of modern work tools, the undisclosed attitude of the university administration towards the lack of available technical department staff, etc. Against this background, this study aims to explore the challenges and prospects of cataloguing and classification in Kwara state university library.

\section{Purpose of the study}

The main purpose of this study is to ascertain the challenges and prospects of cataloguing and classification in Kwara state university library, Nigeria. In this respect, the study is specifically designed to establish:

- Cataloguing and Classification Challenges in Kwara state university library.

- Prospects for the section of Cataloguing and Classification in Kwara state university library.

- The relationship between challenges and prospects for the cataloguing and classification section in Kwara state university library.

\section{Research Questions}

The following research questions were developed to guide the study 1. What are the challenges of the cataloguing and classification section in Kwara state university library? 
2. What are the prospects for the section of cataloguing and classification in Kwara state university library?

\section{Relevant literature review}

This section of the paper reviews the literature on cataloguing, classification, challenges and expectations. Technical department (cataloguing and classification) of the library the academic library in particular is one of the most important sections of the entire library that requires adequate attention. Over the years of working in the technical section of the academic library, the library department did not receive enough attention in some academic libraries. Thus, resulting in many complex challenges that may or may not have a sustainable solution.Esther (2004) enumerated in her study some of the challenges faced by librarians and librarians in the cataloguing and classification department in organizing knowledge to include: employee attitudes towards reading and supervision of shelves, lack of motivation, insufficient reading materials, lack of staff, insufficient orientation, users no longer need to actually visit the library to retrieve the information.

From the point of utility of digital services to cataloguing, Onyemaizu (2019) examines the utility of cataloguing for digital services and the challenges encountered during the process. The digital or online catalog is designed so that documents can be accessed via peripheral devices, so that library users can directly and efficiently search for bibliographic records and retrieve them without the help of a human medium. Despite the benefit of digital cataloguing, such as flexibility, freshness, ease of updating among other things, Nigerian libraries are not practicing digital cataloguing properly due to challenges such as erratic power supply, insufficient funding, staff shortage, and lack of cataloguing experience or knowledge among others. This paper also 
demonstrates that these challenges can be overcome with adequate funds, appropriate personnel and training, and stable power supply.

Cabonero and Dolendo (2013) also studied indexing and classification skills for library and information science practitioners in their workplace. The study identified cataloguing and classification skills for library and information sciences graduates, which focused on evaluating thecataloguingand classification skills of academic and school librarians in three areas: descriptive cataloguing, topic analysis, and classification. The case analysis was used for five practicing librarians who graduated with a Bachelor's degree in Secondary Education majoring in Library Science and a Bachelor's in Library and Information Science from the College of Teacher Education, Benquet State University (BSU).The study results revealed that the cataloguing and classification skills of the five library and information sciences graduates from BSU are generally adept in the basic areas of descriptivecataloguing, topic analysis and classification but found more difficulty in the subject. Isyaku, Bello, and Ado (2018) investigated the challenges and prospects of cataloguing and grading library materials in the libraries of Kano State, northwest Nigeria. The paper focuses on organizing library materials that help to provide efficient, efficient and effective services. The study determined that librarians were no longer interested in indexing and classification units due to their boring natureof course, I like slacking. This is what affects the technical department of all libraries in Kano State. The paper also highlights some of the challenges and prospects, and provides suggestions on how to reduce or eliminate the challenges altogether.

Manaf and Ibrahim (2016) investigated cataloguers 'and classifiers' perceptions of cataloguing and classification practices. The study adopted the descriptive design. All 67 academic librarians working in six selected institutional libraries were studied. The study adopted a questionnaire method to collect data from the respondents. Data were analyzed using inferential statistics. The 
results revealed that librarians had a positive perception of their cataloguing and classification activities. It also appears that the majority of the respondents showed an interest in working in the technical section of the library. It also revealed some challenges that must include: the lack of modern tools, inappropriate work tools and an unfavorable work environment.

Hort (2016) examined the library profession, the risks, and the future of librarians in South Africa. The study adopted the descriptive design. Librarians have been studied in some of the selected academic libraries. The interview method was used to collect data for the study. The results show that the library profession is becoming increasingly profitable and is gaining more attention among young men and women in South Africa. It also reveals some health risks associated with the profession to include: environmental risks, especially from chemicals used to protect books and other materials in the library, and other health challenges, especially for catalogers. The study also shows a more challenging and competitive future for South African librarians.

Likewise, Orbih and Aina (2014) in their study on the issues, advantages, and challenges of original cataloguing versus copy-cataloguing, assert that in the past, cataloguing and classification were performed manually making the workvery difficult, boring and time consuming. Recently, most of university libraries in Nigeria have joined their counterparts in developed countries in using computers to process library collections. The use of computerized cataloguing and classification has made the processing of library collections more accurate, interesting, and faster. The above review etiquette relates to this study. Although some of them are of a theoretical nature but have studied the same subject area. The experimental studies adopted the descriptive design as well as the use of the questionnaire as a tool for data collection, which was also adopted by this study. 


\section{Methodology}

The study adopted the descriptive survey design. The study population consists of 50 practicing librarians who attended the Nigerian Library Association Annual Workshop, Kwara State Chapter 2020 held in State Library. A questionnaire entitled "Challenges and Prospects for Cataloguingand Classification Questionnaire" was used which included closed items to collect data from respondents. Copies of the tool were delivered to 50respondents inside the workshop venue with the help of a SIWESS student. Of the 50 questionnaires that were given to respondents, 45 were returned and used in the analysis. Specifically, the descriptive statistics were used to analyze the research questions and hypotheses using the latest version of Statistical Package for Scientist (SPSS) program. 


\section{RESENTATION AND ANALYSIS OF DATA}

Research question 1: What are the challenges of the cataloguing and classification section in Kwara State University Library?

Summary Table 1: Table of cataloguing and classification challenges in Kwara State University Library.

\begin{tabular}{|c|l|c|c|}
\hline S/N & \multicolumn{1}{|c|}{ ITEMS } & FREQUENCY (\%) & DECISION \\
\hline 1 & Inadequate cataloguing and classification staff & $44(98 \%)$ & AGREED \\
\hline 2 & Lack of up-to-date classification tools & $44(98 \%)$ & AGREED \\
\hline 3 & Difficulties of cataloguing and classifying backlogged & $42(93 \%)$ & AGREED \\
\hline 4 & Using of manual method cataloguing and classification & $40(89 \%)$ & AGREED \\
\hline 5 & Lack of training opportunities specifically for the cataloguers & $40(89 \%)$ & AGREED \\
\hline 6 & Lack of special medical assistance for eyes related issue & $40(89 \%)$ & AGREED \\
\hline 7 & Lack of preferential incentive for technical section staff & $40(89 \%)$ & AGREED \\
\hline
\end{tabular}

The data in the first table reveal that items 1. 44 (98\%), 2. 44 (98\%), 3.42 (93\%), 4. 40 (89\%), 5. $40(89 \%) \%), 6.40(89 \%)$ and $7.40(89 \%)$ all agreed upon what was not agreed. In general, the total agreed repeat score was also greater than the offending scorethis means that respondents are in agreement with the elements indicating different types of challenges that prevent cataloguing and classification in the technical department of the studied library. 
Research question 2: What are the prospects of cataloguing and classification sections in Kwara state university library?

TABLE IISUMMARY TABLE OFPROSPECTS OF CATALOGUING AND CLASSIFICATIONSECTIONS IN KWARA STATE UNIVERSITY LIBRARY, NIGERIA

\begin{tabular}{|l|l|l|l|}
\hline S/N & \multicolumn{1}{|c|}{ ITEMS } & FREQUENCY (\%) & DECISION \\
\hline 1 & Increase advocacy for library automation/ICT adoption for libraries & $40(89 \%)$ & AGREED \\
\hline 2 & Increase training opportunities are available outside the state in Nigeria & $44(98 \%)$ & AGREED \\
\hline 3 & Reduction of eye related problems due to the use of ICT devices & $43(96 \%)$ & AGREED \\
\hline 4 & Introduction of library and information management system & $40(89 \%)$ & AGREED \\
\hline 5 & Regular updating of cat/class knowledge through workshops & $44(98 \%)$ & AGREED \\
\hline 6 & More ICTs facilities are introduce in cat/class sections & $40(89 \%)$ & AGREED \\
\hline 7 & Accelerated move from manual to electronic method & $40(89 \%)$ & AGREED \\
\hline
\end{tabular}

The data in the second table show that item 1. (89\%) 2.(98\%) 3.(96\%), 4 (89\%), 5.(98\%),

6. $(89 \%)$ and 7.(89\%) greater than the degree of repeat variation. In general, the major repeat score of $98 \%$ was also greater than the repeat score. for the cataloging and classification of the technical section of the library investigated. This means that respondents see a brighter future for the cataloguing and classification of the technical section of the library investigated. 


\section{Discuss the results}

The results show that there are many challenges facing the technical divisions (indexing and classification) of the examined library. Hence, these challenges may be more devastating in some libraries than others. The fact that those libraries that still use the manual method may be more vulnerable to some of the challenges indicated by the respondents. The unfortunate thing is that some of these challenges are long-standing problems that can be easily managed if the wellbeing of employees and the department is taken care of. This conclusion is consistent with the results of the study of Manaf and Ibrahim (2016) the study, revealed some challenges facing the technical department to include: the lack of modern tools, insufficient work tools and an unfavorable work environment. Likewise, the findings support Esther's (2004) findings that identified some of the challenges librarians faced in the cataloging and classification department to include: employee attitudes toward reading and supervision of shelves, lack of motivation, insufficient reading material, and understaffing., Insufficient routing, users no longer need to physically visit the library to retrieve the information. The study also revealed future prospects for the technical departments in the academic libraries that were studied. The study indicated that the future of administrations is bright, especially with the increasing adoption of information and communication technology in the Library.

Specifically, the bright future prospects for the divisions may be due to the replacement of the manual method with the computer method of processing the library's collections making it remarkable. This result confirms what was confirmed by Orbih and Aina awareness (2014) in 
relation to cataloguing and classification in which he stated that in the past the cataloguing and classification was done manually which made the work very difficult, boring and time consuming. Recently, most of the university libraries in Nigeria have joined their counterparts in developed countries in using computers to process library collections. The use of computerized cataloging and classification made processing of library collections more accurate, interesting, and faster. This may be one of the reasons why many librarians are interested in this section.

\section{Conclusion}

The study investigated the challenges and prospects of the cataloging and classification sections at Kwara State University Library, Nigeria. From the results of the study, I concluded that there are many challenges facing the cataloguing and classification sections of the Kwara State University Library, Nigeria, as indicated by the majority of the respondents. In addition, it was also concluded that the outlook for cataloguingand classification is very bright as library move from manual process to computerized method of dealing with library collections in the library under investigation. Thus; it was proven from the results of the study that there is no relationship between the challenges and the prospects as indicated by the respondents. There is a bright future in academic library in Kwara State, as more information and communication technologies are still on their way to academic libraries across the state for adoption. 


\section{Recommendations}

Based on the results, the following is recommended to mitigate some of the challenges and also to maintain expected expectations:

1. The library management at Kwara State University Library should fully automate its library to get rid of boring, slow and imprecise services to provide more proactive, accurate, fast and interesting services to its users.

2 The library management in the Kwara State University Library should contain solid and maintainable and sustainable programs suitable for the library environment and usable by the staff in their technical divisions.

3- The Kwara State University Library management should send its technical staff to training programs, short courses, conferences and workshops on topics or areas dealing with online cataloguing and classification, the Resource Description Framework (RDF), resource description and access to them. (RDA) and any other programs related to cataloguing and classification to expose and increase the knowledge of cataloguing and classification personnel 


\section{REFERENCES}

Cabonero, D. A., \& Dolendo, R. B. (2013). Cataloging and classification skills of library and Information science practitioners in their workplaces: A case analysis. Library Philosophy and Practice (e-journal). 960. http://digitalcommons.unl.edu/libphilprac/960

Esther, N. (2014). Organization of knowledge in Nigerian libraries: challenges and prospects. Nigerian Journal of Library, Archival and Information Sciences (NJLAIS), 1 (15), 1 - 12.

Hort, J. N. (2016). Cataloging and risk: cataloguing and classification career. Retrieved September 23, 2017 from http://americanlibrariesmagazine.org/ala-membersblog/cataloging-and risk-cataloguing-classification-career.

Isyaku, M., Bello B. B. \& Ado G. (2018). Cataloguing and classification of library materials in libraries of Kano state, Northwest Nigeria: challenges and prospects. International Journal of Advanced Academic Research (Arts, Humanities and Education), 4(7), 2488-9849.

Manaf, Z. \& Ibrahim, I. (2011). Assessing cataloguers and classifiers' perception towards cataloguing and classification practices in academic libraries in Malaysia. Malaysia: University Technology Mara.Retrieved April 13, 2013 from http//:www.irdci.unitm.edu.

Orbih, D, E. \& Aina, A. J. (2014). Issues, benefits and challenges of original cataloguing versus copy cataloguing: The experience of Lagos State University Library. International Journal of Library and Information Science, 6(5), 88 - 97.

Onyemaizu, C. (2019). Cataloguing for digital services in 21st century Nigerian library: Prospects and challenges.Please contact net for detail. Posigha, B. E., Asaba, J. \& Oberhiri-Oruma (2018). Librarians' interest and perception towards cataloguing and classification in Bayelsa State.Ebonyi Journal of Library and Information Science, 5(1), 178 - 188. 